\title{
The Role of Business Incubators in The Development of Entrepreneurship in Yemen
}

\author{
Hana'a Hibah $^{1}$, Wail Alhakimi ${ }^{2}$ \\ ${ }^{1}$ School of Business, Lebanese International University, Yemen \\ ${ }^{2}$ Associate Professor of Marketing, Taiz University, Yemen \\ Correspondence: Wail Alhakimi, Taiz University, Yemen. E-mail: wail.alhakimi@taiz.edu.ye \\ Received: April 7, 2021 \\ Accepted: September 2, 2021 \\ Online Published: September 10, 2021 \\ doi:10.48110/joi.v2i2.34 \\ URL: https://doi.org/10.48110/joi.v2i2.34
}

\begin{abstract}
This research aims to identify the role of business incubators in developing entrepreneurship and creating new commercial enterprises. The research focuses on the pre-incubation stage, which is the critical stage in shaping the intention of entrepreneurs. It also focuses on factors such as incubator's performance, desirability self-efficacy, facilitation, feasibility, and perceived risk) that affect the success of entrepreneurship projects. The data was collected in the form of two types of questionnaires, a questionnaire for entrepreneurs who are within the incubation program, and a questionnaire for business incubators. The questionnaires were distributed on paper with a cover letter explaining the nature and purpose of the questionnaire. The data was analyzed and checked for reliability, and descriptive statistics were generated based on the data. The results showed that there are no standards to measure and monitor the performance of incubators, and there is no correlation between incubators and other official agencies. The results also revealed that the factors affecting entrepreneurs are closely related to the incubators' performance levels because they affect the success or failure of the incubated projects. The majority of incubates indicated that funding is the main obstacle in their work in addition to the lack of multiple skills. Another finding of this study was that the entrepreneurs who joined the incubator program were inspired by the growth potential and lack of entrepreneurial skills. The current study provides an insight into the role of business incubators in developing entrepreneurship in Yemen. Recommendations are presented in this study for entrepreneurs incubated in the study environment in order to improve their current level, as well as for incubators to develop the level of services within the standards set by specialists and to provide an appropriate environment. Recommendations are also presented for the competent authorities and the foundation that support the incubators in order to organize the incubation process and-set standards.
\end{abstract}

Keywords: Business Incubators, Entrepreneurship, Intention of Entrepreneurs, Incubator's Performance, Desirability, Self-Efficacy, Facilitation, Feasibility, Perceived Risk

\section{Introduction}

Over the last decade society has changed as the consequence of demographic shifts and increased usage of information communications technology. This has influenced the type of entrepreneurship individuals and firms to engage in and the focus of their businesses (Ratten and Dana, 2019). Entrepreneurship is promoted as a solution to high rates of youth unemployment around the world and especially in the Middle East and North Africa (MENA) (Krafft and Rizk, 2021).

Entrepreneurship is a form of empowerment as it provides a way for individuals to pursue their dreams. The generation of ideas is at the heart of entrepreneurship and involves assessing new opportunities. Recognizing gaps in the marketplace that new products, services or processes can fill is central to the idea of entrepreneurship (Ratten, 2020).

The Yemeni economic situation and the position of Yemeni entrepreneurship are presented in light of our current days. In previous studies, many authors agreed that entrepreneurial activities are important to the job opportunities that the country needs, so their growth and continuation represent a great economic importance. According to the Gordon Institute of Business and Science (2009), the growth and continuity of small businesses is directly related to economic growth, job creativity, and poorness reduction. The incubators' initiatives in Yemen are also presented in this paper in addition to the study of the relationship between the government, businessmen, organizations and institutions supporting entrepreneurs' projects. .. 
According to Sashay and Sharma (2009), business incubators are organizations which aim to quicken the succeed growth of entrepreneurial enterprises by providing help for businesses in the form of business network resources, services, and connections. In order for the entrepreneurial enterprises to fully contribute to the economy, they need a full support from business incubators.

The researchers found that there are a large number of businessmen in Yemen. Most of them are pioneers of emerging projects, some of them are still continuing in the business market without any progress, and others could not continue due to the many difficulties they faced that they did not have the ability to overcome, and very few of them were able to grow and progress, but those are presented by a small percentage. Many of these entrepreneurs own innovative and practical projects, but lack commercial skills and, financial and logistical support. If care, attention, and necessary support are provided for these entrepreneurial projects, they will form an effective element in the economic development in the future and therefore unemployment will be reduced. Here, the role of business incubators will play a major and distinct role.

Business incubators offer pioneers with the necessary tools to translate and embarrass their ideas in a logical, meaningful, and purposeful way, and help them bridge knowledge gaps in the pre-incubator stage. It likewise reduces initial operation costs by offering entrepreneurs with a set of distributed services and facilitating their access to external information.

The main problem of failure is that young entrepreneurs do not have enough resources and experience in the early stages of the entrepreneurial process for startups. According to Freeman, Carroll, and Hannan (1983), there are some methods that reduce or prevent the effects of failure. One of them is the rapid growth of businesses, which requires the presence of incubators and their contribution to provide the needs of these startups and to reduce the effects of failure. However, there are very few incubators in Yemen, and these incubators lack the skills to fully contribute to the development of SMEs in addition to the lack of incubator staff who knows what entrepreneurship is. The shortage of entrepreneurial expertise and the failure of the function of business incubators with entrepreneurs' projects in Yemen have led to the failure of most SMEs and their inability to sustain growth, which negatively affects their capability to contribute to economic development.

This study emphasis on the entrepreneurial and incubator platform which helps small and medium enterprises (SMEs) in technology innovation and entrepreneurship. This platform can be created through three components: incubation services, knowledge of entrepreneurship and entrepreneurship financing. Business incubators assist SMEs in accessing innovation and business resources, enhancing their research and development capabilities, and starting new businesses, in order to achieve a more competitive economic and competitive development.

The significance of this study is clear in helping to design appropriate incubation programs for entrepreneurs, proving the importance of the incubators, especially for entrepreneurs, showing the reasons for the failure of entrepreneurs and the incubation process, showing the influence of entrepreneurial characteristics on the entrepreneur, and clarifying the relationship between entrepreneurial intention, incubators, and influenced factors.

Sustainability issues, infrastructure, and market accessibility for the startups are the focus areas of this study for determining the factors. In line with the stated problems, this research is devoted to get solutions/answers to the following questions:

- What is the level of risks to which entrepreneurs' projects are exposed, and what is the extent of awareness of entrepreneurs for these risks?

- What is the current status of incubation in Yemen?

- How effective is the business incubation program for entrepreneurs?

- What is the level of entrepreneurial intention for entrepreneurs and what are the factors that affecting it?

- What is the level of entrepreneurial knowledge and skills for Yemeni businessmen?

\section{Literature Review}

\subsection{Entrepreneurial Intentions}

When creating any small work, there must be an intention for this work, and then the intention will be converted into a realistic project. Through this can be said that the intentions of entrepreneurship are the intentions of the individual to adopt specific activities that lead to the formation of a new project.

Researchers suggested that entrepreneurial intentions may be one of the best predictions of behavior planned for starting a new business, and these intentions generally vary between individuals and can be learned (Fellnhofer, 2017; Krueger \& Brazeal, 1994).

Entrepreneurship is a complex behavior, which follows a planned path as a result of a specific intention (Obschonka et al., 2010). Entrepreneurship intention is defined as "a self- recognized conviction by someone who 
intends to create new business and consciously plans to do so sometime in the future" (Thompson, 2009, p. 676). Intentions turn into behavior that affects the work on the project, and the knowledge that individuals possess. Therefore, intentions enable individuals to perform some of the procedures and steps that affect the way the work progresses. Accordingly, the strongest intentions of entrepreneurs to be entrepreneurs should be the most likely to take any action in their projects. There are other external factors that may affect the intentions of entrepreneurs. When a person decides to become an entrepreneur, basically there is the intention and its positive effect on obtaining a knowledge for beginning and running a business, and this grants a strong relationship between the intent to start a business and the behavior or ability which the individual exhibits to start a business. Martínez, Herrero-Crespo, and Fernandez-Laviada (2015) examined the impact of perceived risk on entrepreneurial desirability and feasibility in a sample of new entrepreneurs, and they found that risk scopes are related to entrepreneurship perceived desirability and feasibility.

Several behavioral science studies supported the effect of the interaction between factors of perceived feasibility and perceived desirability (MacIver, Stipek, \& Daniels, 1991). This indicates that the entrepreneurial intentions as a whole are considered an interaction between feasibility and perceived desire and not a function of effects only.

Individuals must determine what skills they possess are necessary for their success as entrepreneurs and how desirable they are. Brockner, Higgins, and Low (2004) agreed with the prevention-focused approach, which states that since the risks of entrepreneurship are widely recognized, examining the feasibility and establishing the intention to act as an entrepreneur will caution him against making mistakes.

Based on this discussion, hypothesis one is articulated as the following:

\section{H1. There is a negative and significant impact of perceived risk on entrepreneurial intention to inspire a new business.}

\subsection{Risk}

Entrepreneurship in general involves a certain degree of risk. As a result, entrepreneurs understand that they must be prepared to take risks in seeking potential profits. To achieve their strategic plan, a certain degree of risk is required. Besides avoiding some risks, they must remember that some risks are inevitable and necessary, and when managed well, this is beneficial in the long run. For the first time, startup leaders must develop a risk management mindset. The most common definition of risk is that a risk is the possibility that a specific event may have an undesirable negative or positive impact (Leitch et al., 2010). In the business sector, risks have actual cash and operating effect. Each project, by linking in to the market, implicitly accepts risk-taking as a commercial matter. The risks change with different sectors, organizational structure and degree of risk.

Usually, new projects face higher risks for investors. Aligning stakeholder goals is critical to determine the level of risk the organization is prepared to take and how to manage it. Experts agreed on two wide types of risks. The first type is the: miscellaneous risk. It is the type that enables the company to seek assistance from external sources. The second type is the systemic risk. This type of risk must be dealt with within the framework of the business plan that the company follows. Both types must be taken into account in the company's plan, and they are dealt with differently and separately.

There are many types of risks are. Ebben (2005) registered 5 forms: Market risk, Operational risk, Financial risk, Opportunity risk, Recruiting risks, Technology risk, Strategic risk, Political risk, Competition risk. Companies treat technology risk as unsystematic, while competition risk, market risk, financial risk are apparently being considered systematic. The results of previous studies indicated that perceptions of entrepreneurial risks are not considered important to the entrepreneurial intention. These results are relatively in agreement with the results of the study of Fedáková et al. (2018), which studied the perception of the risks of entrepreneurship and the entrepreneurial intention of a sample of 413 employees and unemployed. showed that the two samples did not indicate serious intentions for the entrepreneurial business, and for their awareness of the level of risks related to entrepreneurship. Therefore, the link between the intention of entrepreneurship and the perception of the unemployed of the risks was great. Negatively, this indicates that the lowest level of entrepreneurial intent can be influenced by high-risk perception.

On the contrary, employees' reports indicated that the lowest level of entrepreneurial intention was associated with a more risk-intensive perception. However, this could explain the fact that the employees feel safe and satisfied with their situation.

Nevertheless, Martínez et al. (2015) stated in their study of the effect of perceived risk on entrepreneurial desirability and feasibility in a sample of 376 new entrepreneurs in Mexico that the risk dimensions are associated 
with perceived entrepreneurship, desirability, and feasibility.

Traditionally, risk is one of the obstacles standing in the way of entrepreneurship, and speculation about potential losses arising from business operations negatively affects entrepreneurial intentions (Janney and Dess. 2006; Keh, Foo, Lim, 2002).

Based on this discussion, hypothesis two and three are articulated as the following:

\section{H2. The perceived risk in entrepreneurship is adversely affects the perceived desirability for entrepreneurship.}

\section{H3. The perceived viability of entrepreneurship is adversely affected by the impact of perceived risks.}

Other authors such as Kickul, Gerhardt, and Barbosa (2007); Dickson and Giglierano (1986) stated that entrepreneurs could view both threats and opportunities (linked to the potential profits of new business). However, experimental support for this path remains bounded. Therefore, this research is based on the traditional concept which states that perceived risk has a negative impact on entrepreneurial behavior.

\subsection{Self-Efficacy}

Starting a business and carrying out entrepreneurial activities indicates people's self-confidence and is considered an indicator of self-efficacy of entrepreneurship (McGee, Mueller, Peterson, \& Sequeira, 2009; Chen, Greene, \& Crick, 1998). According to Bandura (1991), self-efficacy is a motivating machine that performs two processes to achieve the goal: first, enhancing the progress of goals and second, strengthening the connect between goals and achieving the goal. For the first function, the study provided evidence that the self-efficacy of entrepreneurs has a positive effect on improving entrepreneurship goals. The views of entrepreneurial intention are obtained from the formulation of self-efficacy.

According to Bandura (1986) and Bandura and Adams (1977), self-efficacy is a powerful indicator of entrepreneurial intentions as the likelihood for starting an activity can be illustrated by the person's belief in his capability to carry out a specific behavior. So, self-efficiency can be used as a measure of feasibility, as selfefficacy is linked to feasibility.

Based on this discussion, hypothesis four is articulated as the following:

H4. The perceived feasibility of entrepreneurship is favorably affected by the perceived self-efficacy of entrepreneur.

\subsection{Facilitating}

Researchers knew that facilitating means enabling elements or barriers in the environment, and it affects an individual's awareness of the ease or difficulty in performing the task. It is an organizational and technical infrastructure that supports the use of acquired systems.

Business management includes administrative skills, as it has a joint effect in facilitating the tasks of entrepreneurship. Therefore, the role of the business incubator in sponsoring SMEs is important for the development and sustainability of the incubated business. Therefore, it can be said that empowering entrepreneurs with the skills required for entrepreneurs may lead to creativity and innovation at work, and thus they help in achieving the goal of entrepreneurs by achieving the goal of incubators. Incubators provide the services and assistance required in the development and growth of incubated projects to ensure the success of entrepreneurs, especially when they graduate from the incubator. Among the factors that facilitate entrepreneurship are:

- Previous knowledge and experience.

- Supporting banks and financial institutions.

- Availability of an experienced and skilled person in the family.

- Self-motivation skills and experience.

So, the perceived feasibility of entrepreneurship is affected by the conditions of facilitation by entrepreneurs.

Based on this discussion, hypothesis five is articulated as the following:

H5. The perceived facilitating conditions by the entrepreneur exert a positive influence on the perceived feasibility of entrepreneurship.

\subsection{Business Incubator Performance}

A business incubation is a supporter of entrepreneurs, which helps them in the successful growth by providing them with the services and resources they need (NBIA, 2009). 
The researchers found that business incubator is one of the economic development tools that accelerate the growth of entrepreneurial projects by providing resources and services to support entrepreneurial projects which often lack resources, or those which cannot afford new costs. So, incubators try to classify the failures of entrepreneurship projects such as: information costs, lack of services, and large number of failures among startups. During the business establishment process, business incubators provide their services oriented directly towards self-efficacy for entrepreneurs to increase and raise efficiency during the construction process. The main problem of failure is that young entrepreneurs do not have enough resources and experience in the early stages of the entrepreneurial process. That is called 'Responsibility of Modernity' means that startups face risks such as the employee's unclear role, legitimacy, internal coordination and competitiveness in relation to old firms (Stinchcomb, 1965).

According to Freeman, et al. (1983), there are some methods to reduce or prevent the effects of the 'Responsibility of Modernity' and one of them is the rapid growth of a company or business. However, there is the problem of the need for financial resources, which entails:

- The inability of startups to employ skilled workers.

- Difficulty in paying administrative expenses related to compliance with government regulations.

Besides, there are various problems that can occur during the start of a new business, and the need for external support is crucial for a successful business development. This support can be obtained from business incubators. So, the business incubator is one of the helpers who can help with that.

Incubators that provide financing assistance for the development of incubated projects can help in a number of ways, including assistance in creating economic and social stability, as they aim to develop their performance in the incubation process. In their research paper, Wiggins and Gibson (2003) listed five factors that must be in place for a business incubator to succeed. The factors are as follows:

1. Setting clear standers for success.

2. Providing entrepreneurial leadership.

3. Developing and providing new services to the firms' members.

4. Developing a logical new firm's chosen operation.

5. Ensuring that companies get the required support.

At the start of the productive process for entrepreneurs, it is necessary to organize, this organization, includes many activities such as activities that generate protection and continuity in the production process and those that ensure its growth and development by exploiting and maintaining available opportunities (Shane, 2003) through the creation of complementary procedures and structures to match strategies.

Business incubators could adopt different strategies for incubating startups. The most complicated strategy for incubator, and the most valuable one for an entrepreneur is the way when incubator links the processes and phases of incubation to entrepreneurial life cycle. This method means that business incubator should have resources, processes, and instruments for pre-incubation, incubation, and post-incubation stages.

Several authors such as Stephens and Onofrei (2012), Krueger (2009), and Peterman and Kennedy (2003) said that the beliefs and attitudes that an individual acquires through training and gained entrepreneurial experience are greatly influenced- by the individual. This means that the incubator services should be provided in the preincubation stage, which is the pre-establishment stage of work that helps to form the perceptions and intents of the incubated individuals.

In this stage, the positive attitude of entrepreneurship is reinforced and thus it is considered a positive career alternative (Kickul, 2006) which rises the perceived desire in an entrepreneur (Kuehn, 2008). Business incubators are the best solution to market failures. Nesta (2011) pointed out that one of the reasons these failures generate the high costs and risks associated with supporting startups is that the potential return from start-up is uncertain and thus organizations are not prepared to absorb the costs and risks associated with support. Therefore, incubators provide services that support entrepreneurs, aim to raise the success rate of emerging companies (Hackett \& Dilts, 2004), and aim to raise the level of performance in terms of employment, sales, or profitability (Schwartz, 2011; Delmar \& Wiklund, 2008). Gifford (2010) also noted that logistical support, such as training and consulting services, increases the validity and strength of decisions and reduces the risk involved. Moreover, Wirsing et al. (2002) stated that pre-incubation services help incubators test their business ideas, and thus they help in reducing the risks of starting a business. Therefore, incubating entrepreneurs should be appreciative of the services provided by the incubators for them.

Pomba (2013) argued that incubators save time and money by accelerating the growth of the enterprise, and that is in a business-friendly environment in the start-up stage. Incubators help to reduce the costs of beginning an 
enterprise, to increase the trust of entrepreneurs, and to connect them with the networks and resources that are needed to expand the business. Stevens and Onofre (2012) and, Voise, Gornall, and Jones (2006) viewed that business incubators generate rise in the entrepreneurial professionalism, improvement in the business management skills, and increasement in self-confidence. Thus, this enhances self-efficacy to implement this type of behavior. Buys and Mbewana (2007) said that the success of the incubation program is determined by the quality of the incubated entrepreneurs, and that there must be a desire among entrepreneurs to succeed, learn, and take calculated risks.

Based on this discussion, hypothesis six to nine are articulated as the following:

H6. The entrepreneur's perception of the incubator's execution in providing the required services and support is favorably and directly affected by the desire to entrepreneurship.

H7. The entrepreneur's perception of the incubator's execution in providing the required services and support is adversely and directly affected by the risk to entrepreneurship.

H8. Entrepreneurs' perception of the incubator's performance in providing services directly and favorably affects the perceived self-efficacy of entrepreneurship.

H9. Entrepreneurs' perception of the incubator's performance in providing services directly and favorably affects the perceived facilitating conditions for entrepreneurship.

Sustainability is the ability to achieve continuous improvement and to obtain positive cash flow in the near future for partnerships and stakeholders" (Lalkaka \& Shaffer,1999, p. 11). For the incubator to be sustainable and empowered, financial support must be provided through partnerships and shareholders. The advanced technology of the incubated projects also helps the incubator continue to be sustainable.

Ndedi (2009, p. 467) suggested that "these incubators should also provide potential young entrepreneurs with information on suitable space and flexible leases on the market, common core business services and equipment, technology support services and assistance in securing financing for sustainable company growth".

\subsection{Desirability}

It is defined as the attraction to the idea of starting a new business at a pre-decisional phase. The desire to establish a new business project is determined from by the individual's beliefs and perceptions of what may result from engaging in this project (Singh, Raut, \& Prasad, 2012; Shapero \& Sokol,1982). The concept of perceived risks in the field of entrepreneurship means that there are different types of potential negative consequences derived from this behavior, which can create different impacts on the desire for entrepreneurship.

According to review of the literature, research hypotheses have suggested that the perceived risks of economic, social, time, health, and personal to entrepreneurship unfavorably affect the desirability of entrepreneurship.

The literature has shown that individuals who have a high desirability for entrepreneurship tend to improve high entrepreneurial intention their behavior (Barton, Schaefer, \& Canavati, 2018, Boukamcha, 2015), as desirability is closely related to intention and intention is considered a specific indicator of entrepreneurship. Therefore, the power of the desire to entrepreneurship comes from the power of intention towards the goal. As previous studies indicated, entrepreneurial desire and entrepreneurial intent are among the main factors of the entrepreneurial process.

Based on this discussion, hypothesis ten is articulated as the following:

\section{H10. Perceived desirability of entrepreneurship is favorably correlated with entrepreneurial intentions.}

\subsection{Feasibility}

The feasibility study was formulated in order to be familiar with the main issues of the business idea in order to identify the obstacles so that they can be 'make' or 'break'. It is one of the factors that is considered an obstacle to successes in the market (Echetama, Obi, \& Joel, 2016). The feasibility study is a preliminary evaluation of the business idea, that determines whether the idea is worth pursuing. Sokol and Shapero (1982) defined perceived feasibility as the degree to which people believe that they can start a successful business. Its importance for the businessman includes that he works as a candidate, and it excludes ideas that lack the ability to build a successful business before the businessman commits himself to the resources required for capital. It also helps entrepreneurs in collecting the information required to evaluate a business concept, including lawful requirements, compliance requirements, costs, and marketing. It opens the eyes of the entrepreneur to new chances or ideas that can modify the range of the project. Business feasibility study is a controlled process that identifies problems, opportunities, and goals, describes the situation, analyzes costs and benefits, defines results, evaluates them, and determines the 
project's financial and economic viability.

The researchers mentioned the components of the feasibility study: Technical feasibility, Economic feasibility, Legal feasibility, Operational feasibility, Schedule feasibility, Resource feasibility, Market feasibility.

There is a theory that indicates that entrepreneurial intentions are mostly a task of perceptions of desire and perception of viability (Krueger et al. 2000, Brazeal \& Krueger,1994). According to Steel \& Konig (2006), perceived feasibility is in line with expectations, and perceived desirability is in line with parity. Consequently, this indicates that there is an interaction between the perceptions of feasibility and perceptions of desirability to form an individual's intention to become an entrepreneur. When this interaction occurs, it will have a role in understanding entrepreneurial behavior, as strong entrepreneurial intentions will be shaped to act entrepreneurial.

Based on this discussion, hypothesis eleven is articulated as the following:

\section{H11. Perceived feasibility of entrepreneurship is negatively correlated with entrepreneurial intentions.}

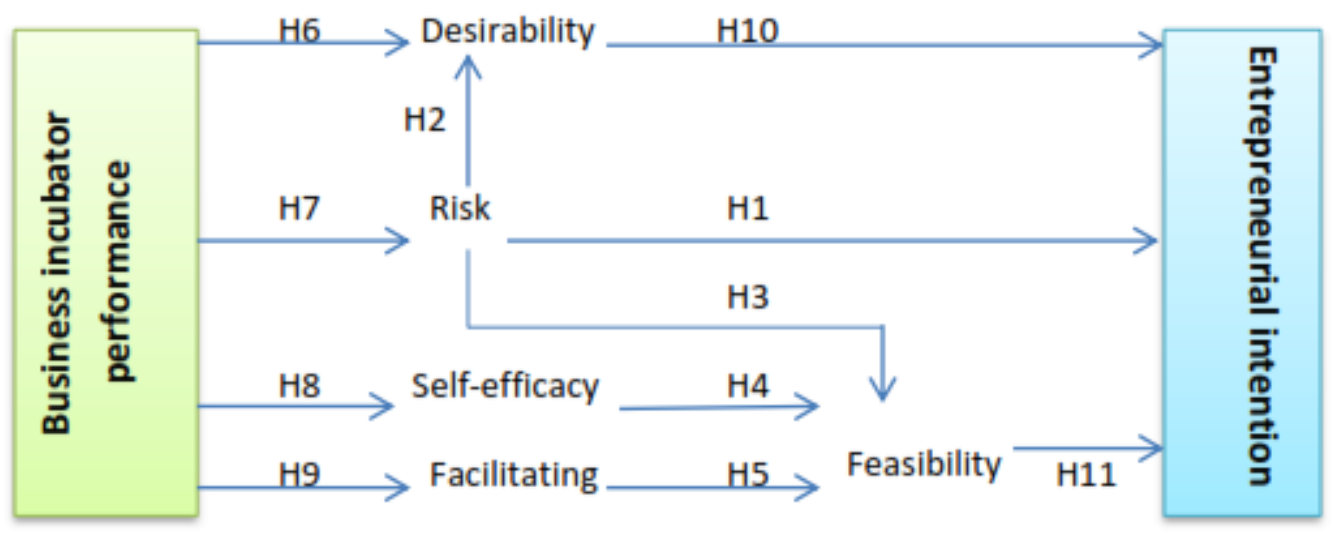

Figure 1. The Conceptual Framework

\section{Methods}

Quantitative research approach is followed, whereby hypotheses are mentioned and formulated in advance, data are in the form of numbers from accurate measurements, and by using statistical methods they are analyzed. The target group in this research was the entrepreneurs who ran a project and were through an incubation program. The community of this study consisted of entrepreneurs who benefited from business incubators. There are no official records available for all companies participating in the incubation program. Due to the limited number of business incubators, business incubators in Sana a were considered suitable for inclusion in this study. A representative sample of entrepreneurs also drawn about the incubation programs. Since then, the incubation program has become fragmented. There is also a lack of information and data inaccuracy. In addition, there was unwillingness of the private sector and the public sector to exchange information and monopolize it. Therefore, the study used a non-probability target sample. Non-probability convenience sampling is the method used for collecting information from a population's participants who are conveniently available to provide it. Therefore, due to the cost, time effectiveness, and difficulties in reaching the samples at the same time of data collection, convenience sampling was selected. It is proven that the larger the number of participants in the sample is, the more accurate the results can be. As a result, it is important to ensure a certain size of sample in this study. Roscoe (1975) mentioned that a sample size can be taken greater than 30 and smaller than 500, and this number will be suitable for a lot of researches. The size of the sample was determined by 35 people, including incubated entrepreneurs and entrepreneurs who had previously incubated and whose incubation period had expired.

The techniques used to gauge entrepreneurial intention, desirability, and feasibility were mapped from the studies of Liñán and Chen (2009) and Finisterra Do Paço. et al. (2011). Measures of perceived risk were determined from the proposals of Liao-Troth, Kickul, and Barbosa (2007). The self-efficacy measure was identified from Kickul (2006) and Ehrlich, De Noble and Jung (1999), while the measure of facilitation was set based on Edelman and Yli-Renko (2010). Finally, the method of the performance of business incubators arising from their providing services was improved (Meru and Struwig, 2011).

The overall reliability is achieved (Cronbach alpha $=0.885$ ). The Cronbach's Alpha for the seven dimensions being tested in the questionnaire show that all the dimensions of the study have reliability and internal consistency 
(Cronbach's Alpha $>0.700$ ) indicating that the tool of the study is reliable. Moreover, the validity of the instrument was measured using correlation analysis which shows a statistically significant correlation between the overall average of the study constructs and its items, indicating that the construct explains adequate variance in its items and thus has good validity to measure what is it supposed to measure.

\section{Findings}

\subsection{Business Incubators}

Eight incubators were targeted, and only 6 of them accepted to cooperate. $90 \%$ of the incubator managers are between $31-40$ years old, their educational level is university education. It is evident from the survey that five out of the six incubators indicate that their incubators are less than five years old, while only one incubator is more than five years old. The study also found that $80 \%$ of business incubators are new. In other words, the incubators lack the skills necessary to fully participate in the expansion of SMEs, as they lack the expertise and skills necessary to effectively manage the incubator. The survey showed that all incubators provide training courses and logistical services, and they do not have any specific criteria for the selected projects. The survey showed that three of the six incubators that were subjected to the study are self-financing because they are still new and are looking for funding from organizations and the private sector. The other three incubators cover the cost of operating the incubators from international organizations, civil society organizations, and private sector institutions. The results indicated that the most important challenges facing the incubators in all the six incubators are the lack of funding or the lack of continuity of the incubated projects, in addition to the fact that some incubators indicated a lack of commitment to the incubators, because they found better and cheaper support services in another place. All incubators emphasized that the lack of entrepreneurial skills impacts the performance of the business incubators. This emphasizes the need to possess entrepreneurial skills, as these types of skills are considered entrepreneurship. There is a lot of work being done to make sure that the business is successful, and if these skills are not available, entrepreneurs will not be capable to grow at a sustainable rate which enables them to grow as a company and as individuals.

Through the field survey of business incubators, the following points were found:

- Managers of incubators do not have a clear vision of the process of incubating the pioneers and they lack the skill to manage emerging and small projects. In addition to the fact that most of the managers are not qualified to manage the incubators.

- Although international organizations support incubators so that incubators can provide adequate support to entrepreneurs, four from six incubators focus on the financial side and the profitability of incubators, so they rent offices with services from $\$ 40$ - \$ 60 per month, so that one room has 5 to 6 offices.

- Some incubators were established for the purpose of financial gain through renting offices and providing services, and others for material exploitation through obtaining and benefiting from the aid provided by international organizations.

- Very few incubators were able to provide their services as they should.

\subsection{Entrepreneurs}

A survey questionnaire was sent to more than 35 business men and women. The overall response was 35 . The distribution frequency of gender. $57.1 \%$ of the study sample are males while $42.9 \%$ of them are females. It is noticeable that the majority of entrepreneurs are males, and this is due to the fact that some women undertake selffinanced home entrepreneurial projects without engaging in incubator programs, and in recent times, with the increase in the number of organizations in Yemen, the chances of employing females in organizations have increased more than males.

The education frequency distribution of the sample. $17.1 \%$ of the participants in the study sample have secondary education, $62.9 \%$ of them have university education, and $20 \%$ of them have higher studies education. This is because most of the youth have education levels less than university education, and therefore, they do not possess sufficient knowledge that enables them to enroll in incubation programs. On the other hand, young graduates who have recently graduated from universities do not have sufficient experience in the labor market, so the doors of employment are closed to them, and as a result, the door which is open to them is the door of entrepreneurship and incubators.

The frequency distribution of age groups. $65.7 \%$ of the study sample are 22 years old or less, $25.7 \%$ of them are aged between 23-30 years, and 8.6\% of them are aged between 31-39 years. The results clearly showed that the majority of entrepreneurs of the age group 22 or less participate in the incubation program, and the percentage of entrepreneurs participating decreases as they age, due to three reasons: 
- Young people of this age are more willing to take risks.

- Some incubators target this age group.

- The economic situation in recent times has pushed young people to search for job opportunities to improve their living conditions.

Majority of participants in the study ( $80 \%$ ) have previous information about business incubators while only $20 \%$ of them do not have any information about that. This is due to the local media coverage of entrepreneurial competitions and their incubation, as well as to the encouragement of youth organizations to think entrepreneurial and join incubators to realize these projects. Moreover, $45.70 \%$ of the respondents stated that their resources of information come from academic courses, $17.10 \%$ mentioned training courses, as their source, $2.90 \%$ stated that workshop is their source, $5.70 \%$ mentioned brochures as their source, while $8.70 \%$ stated other sources such as reading, internet, or a friend. This is due to the recent trend in universities that provides courses on entrepreneurship and also because some universities are directed to open majors in entrepreneurship and are encouraging students to go to entrepreneurial projects.

More than half of the respondents (57.1\%) stated that the objective of attending a business incubation program for growth, while $17.1 \%$ reported that their objective is skills. The objective of $22.9 \%$ is finance, and $2.9 \%$ reported that network is their objective. It is noted here that the largest percentage of the goal of attending the incubator program by entrepreneurs is growth. This was due to the faltering of many emerging enterprises and their inability to grow and continue, and this is due to the lack of skills necessary for project management and financial and logistical support. Most of the respondents stated that they did not achieve the objectives due to reason of the lack of experience. It is due to the lack of sufficient experience in some incubators to manage the incubators and their inability to meet the needs of incubates in terms of training and logistical support.

The majority of the study sample (77.1\%) stated that the incubator program was effective for their business while only $22.9 \%$ of them stated it was not effective. $77 \%$ of the participants were owners of existing projects and they lacked training in project management skills, so the incubator program was effective for their businesses. On the other hand, the lowest percentage, stated that, the incubator program was ineffective because it was a start-up enterprise that needs financial, logistical and training support.

The normality test was examined using kurtosis and skewness. The skewness and kurtosis of all the dimensions of the study are within -1 and +1 , which indicates that the data of the study follows normal distribution. As a result, there are no concerns about the normality of the data.

Descriptive Analysis of Entrepreneurial Intention in Table 1 shows that item2 "My professional objective is to create my own business in less than one year" was ranked as the highest with a Mean $=4.290$ and a Standard Deviation $(\mathrm{SD})=0.825$ while item 4 "I will do anything possible to create my own business in less than one year" was ranked the lowest with a Mean $=4.060$ and $\mathrm{a}(\mathrm{SD})=1.027$. The overall Mean of the dimension is 4.164 and the (SD) 0.717 which indicates high level of entrepreneurial intention between entrepreneurs.

Table 1. Descriptive Analysis of Entrepreneurial Intention

\begin{tabular}{llllll}
\hline No & Item & Mean & SD & \% & Label \\
\hline 1 & $\begin{array}{l}\text { "I have the clear intention to create my own business in less than } \\
\text { one year". }\end{array}$ & 4.260 & 0.886 & $85.2 \%$ & $\begin{array}{l}\text { Very } \\
\text { "My professional objective is to create my own business in less }\end{array}$ \\
2 & 4.290 & 0.825 & $85.8 \%$ & $\begin{array}{l}\text { Hery } \\
\text { than one year". }\end{array}$ \\
3 & $\begin{array}{l}\text { "I am determined to create my own business in less than one } \\
\text { year". }\end{array}$ & 4.060 & 0.906 & $81.2 \%$ & High \\
4 & $\begin{array}{l}\text { "I will do anything possible to create my own business in less than } \\
\text { one year" }\end{array}$ & 4.060 & 1.027 & $81.2 \%$ & High \\
$\quad$ Entrepreneurial Intention & $\mathbf{4 . 1 6 4}$ & $\mathbf{0 . 7 1 7}$ & $\mathbf{8 3 . 3 \%}$ & High \\
\hline
\end{tabular}

For hypotheses testing, Path analysis model of structural equation modelling was used instead of multiple regression analysis for the following reasons:

1. There is more than one dependent variable in the model.

2. The model of regression is complex.

3. The sample size is small.

4. Multiple regression cannot analyze models with more than one dependent variable.

Table 2 shows the R Square values which indicate the rate of variance explained by the independent variable in the dependent variables. $27.2 \%$ of the variance in the desirability is explained by business incubator performance 
and perceived risk. $11.7 \%$ of the variance in the entrepreneurial intention is explained by perceived risk, desirability and feasibility. $5.4 \%$ of the variance in the facilitating condition is explained by business incubator performance. $29.6 \%$ of the variance in the feasibility is explained by perceived risk, facilitating conditions, business incubator performance, and self-efficacy. $15.4 \%$ of the variance in the perceived risk is explained by business incubator performance. $17.2 \%$ of the variance in the self-efficacy is explained by business incubator performance.

Table 2. Hypothesis Testing

\begin{tabular}{ll}
\hline Dependent variable & R Square \\
\hline Desirability & 0.272 \\
Entrepreneurial Intention & 0.117 \\
Facilitating Conditions & 0.054 \\
Feasibility & 0.296 \\
Perceived Risk & 0.154 \\
Self-Efficacy & 0.172 \\
\hline
\end{tabular}

Table 3 and Figure 2 show that perceived risk has no statistical impact on entrepreneurial intention (Beta $=-0.002$; $\mathrm{t}=0.017), \mathrm{p}>0.05)$ and thus, $\mathrm{H} 1$ is rejected. Perceived risk has no statistical impact on desirability (Beta $=0.119$; $\mathrm{t}=0.616 ; \mathrm{p}>0.05$ ). Thus, $\mathrm{H} 2$ is rejected.

The first and second hypotheses were rejected statistically, and this is due to the type of the sample, as most of the entrepreneurs who were subjected to the sample were young and did not go through an experience, Therefore, they depended on self-management of projects outside business incubators, and they did not have the slightest idea of the size of the risks that they may face in the future, which might be an obstacle for them to continue and progress. These two hypotheses can be achieved with entrepreneurs who have previous experience or acquired self-experience that makes them aware of the size of the risks that they may face in the future, and thus have a negative impact on their desirability and intention to establish a new business.

Perceived risk has a negatively statistical impact on feasibility (Beta $=-0.335 ; \mathrm{t}=2.102 ; \mathrm{p}<0.05$ ). Self-efficacy has a positivelystatistical impact on feasibility (Beta $=0.309 ; \mathrm{t}=2.946 ; \mathrm{p}<0.05)$. Facilitating conditions has no statistical impact on feasibility (Beta $=0.116 ; \mathrm{t}=0.709 ; \mathrm{p}>0.05$ ). During the survey of the sample, it was observed that approximately $90 \%$ of the entrepreneurs do not have the slightest idea of project management and that they are still under training for this skill, so the questionnaires were filled out at this point without knowledge of the effect of the facilitation conditions on the perceived feasibility. Business incubator performance has a positively statistical impact on desirability (Beta $=0.510 ; \mathrm{t}=3.321 ; \mathrm{p}>0.05$ ). Business incubator performance has a negatively statistical impact on perceived risk (Beta $=0.415 ; \mathrm{t}=3.323 ; \mathrm{p}>0.05$ ). Business incubator performance has a positively statistical impact on self-efficacy (Beta $=-0.393 ; t=3.309 ; p>0.05$ ). Business incubator performance has no statistical impact on facilitating conditions (Beta $=0.232 ; \mathrm{t}=1.556 ; \mathrm{p}>0.05$ ). This is because four incubators out of the six targeted incubators were self-financing that provided their services to entrepreneurs at a cost relative to entrepreneurs. This cost is acceptable compared to their projects if they are implemented outside the incubator, but at the same time it is a burden on entrepreneurs, so the performance of these incubators in providing services has no statistical effect on the facilitating entrepreneurship. Desirability has a positively statistical impact on entrepreneurial intention (Beta $=0.338 ; \mathrm{t}=2.170 ; \mathrm{p}<0.05$ ). Feasibility has no statistical impact on entrepreneurial intention (Beta $=-0.009 ; \mathrm{t}=-0.047 ; \mathrm{p}>0.05$ ). This is because most of the projects started with an idea and do not have any feasibility study, so the feasibility work is done during the project management skill training.

Table 3. Hypothesis Testing

\begin{tabular}{lllll}
\hline & PATH & BETA & T & P \\
\hline H1 & Perceived Risk -> Entrepreneurial Intention & -0.002 & 0.017 & 0.986 \\
H2 & Perceived Risk -> Desirability & 0.119 & 0.616 & 0.538 \\
H3 & Perceived Risk -> Feasibility & -0.335 & -2.102 & 0.036 \\
H4 & Self-Efficacy -> Feasibility & 0.309 & 2.946 & 0.003 \\
H5 & Facilitating Conditions -> Feasibility & 0.116 & 0.709 & 0.479 \\
H6 & Business Incubator Performance -> Desirability & 0.510 & 3.321 & 0.001 \\
\hline
\end{tabular}




\begin{tabular}{lllll}
\hline & PATH & BETA & T & P \\
\hline H7 & Business Incubator Performance -> Perceived Risk & -0.393 & -3.323 & 0.001 \\
H8 & Business Incubator Performance -> Self-efficacy & 0.415 & 3.019 & 0.003 \\
H9 & Business Incubator Performance -> Facilitating Conditions & 0.232 & 1.556 & 0.120 \\
H10 & Desirability -> Entrepreneurial Intention & 0.338 & 2.170 & 0.031 \\
H11 & Feasibility -> Entrepreneurial Intention & -0.009 & -0.047 & 0.962 \\
\hline
\end{tabular}

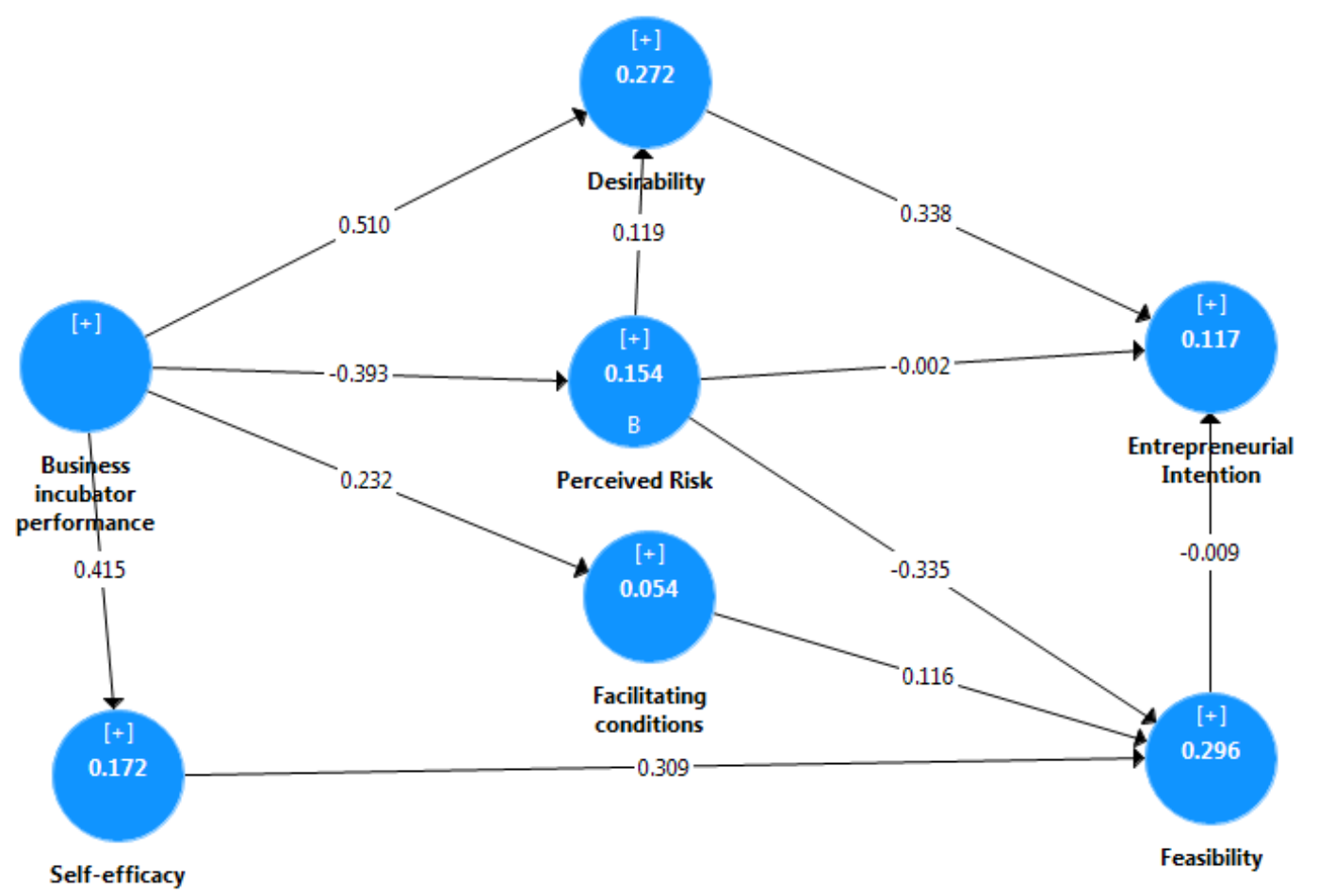

Figure 2. Hypothesis Testing

\section{Discussion and Conclusion}

The purpose of this research is to clarify the status of the current business incubation centers in Yemen and to verify the characters that business incubators play in facilitating the entrepreneurial skills of entrepreneurs that do not have the skills necessary to maintain their entrepreneurial projects. The study also aims to identify areas of work, level of awareness, and the most important (main) services provided by business incubators. It also assesses the impact of business incubators on the factors of entrepreneurship and the main factors that could affect sustainable business incubator models for growth in innovation and entrepreneurship in Yemen. The main objective of this research is to determine the entrepreneurial factors of entrepreneurs and the effect and impact of these factors (desire, risk, perceived feasibility, self-efficacy, and facilitation) on entrepreneurial intention. The research also aims to classify the impact of entrepreneurial factors on the intentions of entrepreneurs, to check the degree of knowledge and entrepreneurial skills of Yemeni entrepreneurs, and to identify the main factors that must be addressed to adopt sustainable business. In seek to facilitate the presentation of the results, they are presented according to the study questions.

The following is the presentation of the results of the study and the answers to its questions: The first question is: "What is the level of risks to which entrepreneurs' projects are exposed, and what is the extent of awareness of entrepreneurs for these risks?". The descriptive analysis showed that the perceived risks are high, so the level of different risks that the entrepreneurs' projects are exposed to is high, and they threaten the continuity of the projects that have been realized. Thus, the first objective, which aims to determine the level of different risks among entrepreneurs, has been achieved. The results of the analysis also proved that entrepreneurs do not have sufficient awareness of these risks and their impact on their projects, because the majority of the respondents in the study sample are those who did not complete the incubator program. In addition, the level of training in project management in most of the incubators is weak and without a clear methodology and reference, and it is considered 
a purely theoretical training. Consequently, they do not have sufficient background in project management and risks' facing. These findings are supported by Fedáková et al. (2018). In reference to the perception of the risks of entrepreneurship and the entrepreneurial intention, the results of the research didn't indicate serious intentions for the entrepreneurial businesses because of their awareness of the level of risks related to entrepreneurship, as the level of risks to which the projects of entrepreneurs are exposed to is a high, which affects the desire and intention of entrepreneurship. As a result, the first hypothesis which states that there is a negative and significant impact of perceived risk on entrepreneurial intention to generate a new business, and the second hypothesis that states that the perceived risk in entrepreneurship negatively effects the perceived desirability of entrepreneurship have not been fulfilled.

The second question is: "What is the current status of incubation in Yemen?". The results of the analysis revealed that the status of business incubators in Yemen from the point of view of entrepreneurs participating in the incubator program is of a high level, because the projects have not been implemented on the ground so that they can properly assess the situation from the reality of implementing projects to identify strengths, weaknesses, threats, opportunities, advantages, and disadvantages of the incubator and the insufficiency that results in weak outputs. Nesta (2011) indicated that market failure may occur due to the high costs and risks connected to supporting start-up projects. Therefore, the services offered by business incubators aim to rise the company's probability of success (Dilts \& Hackett, 2004) and improve its performance in terms of recruitment, sales, or earning (Schwartz, 2011; Delmar \& Wiklund, 2008). It should be mentioned that entrepreneurs suffered from the rent that they pay to the incubators, and it constitutes a burden on entrepreneurs, and therefore the performance of these incubators in providing services has no statistical effect on the facilitating conditions as stated in hypothesis 9 which states that "entrepreneur's perception concerning the incubator's performance in providing services directly and positively affects the perceived facilitating conditions for entrepreneurship". Thus, the second objective which examines the current status of business incubators in Yemen has been achieved.

The third question is: "How effective is the business incubation program for entrepreneurs?". The results of the study indicated that $77 \%$ of the respondents were owners of existing projects and lacked training in project management skills, so the incubator program was effective for their business, as these entrepreneurs focused on making the most of the services provided by the incubator that met, even partially, their need for them. This is confirmed by the hypothesis that states that the project owner's perception regarding the incubator's performance in offering services has a positive impact on the desire for entrepreneurship, as the incubator program covered some weaknesses of entrepreneurs, which positively affected the desire for entrepreneurship. The lower percentage was for the item which indicates that the incubator program was ineffective, because the entrepreneurs whose projects were still under construction needed financial, logistical and training support. Most of the incubators did not provide financial support to the entrepreneurs. On the contrary, they rented out incubation services to entrepreneurs, and this was a burden on the entrepreneurs. $62 \%$ of entrepreneurs reported that their goal of joining the incubator program is to develop their enterprises as they lack the necessary skills and need support that helps them grow. 37\% of entrepreneurs reported that they lack entrepreneurship skills, which have a role on the continuation and growth of entrepreneurial projects. Hence, the goal of all entrepreneurs in the incubator program is the continuity and growth, but what happens is that few of these institutions cannot grow due to the poor performance of these incubators, and this affects the risks of entrepreneurship. This finding validates the hypothesis that states that the project owner's perception of the "incubator's performance in providing services directly and negatively affects the perceived risks of entrepreneurship". The opposite happened with a small percentage of entrepreneurs who were among the incubator programs and who were able to benefit from the services in a positive way. Their impact was directly and positively reflected on the entrepreneur's self-efficacy, as stated in the hypothesis which states that "the entrepreneur's perception regarding the incubator's performance in providing services directly and positively affects the perceived self-efficacy of entrepreneurship". Thus, the third objective which examines the role of business incubators in entrepreneurial projects and their impact on the continuity and growth of entrepreneurial projects, has been achieved. The main problem is that young entrepreneurs do not have sufficient resources and experience in the early stages of the entrepreneurial process, which is called 'modernity Responsibility' (Stinchcomb, 1965). Freeman et al. (1983) stated that there are some ways to reduce or prevent the effects of 'responsibility of modernity' and one of them is the rapid growth of a company or business. This is the responsibility of incubators to help entrepreneurs to successfully overcome this stage.

The fourth question is: "What is the level of entrepreneurial intention for entrepreneurs? and what are the factors that affect it?". The study results indicate a high level of entrepreneurial intention. It was also found that desirability is closely related to intention. This finding validates the literature that has shown that individuals with a high desirability for entrepreneurship tend to improve high entrepreneurial intent and subsequent behavior (Barton, Schaefer, Kanafati, 2018. Segal., Borgia, Schoenfeld, 2005. Boukamcha, 2015). This validates the 
hypothesis that states that a perceived desirability for entrepreneurship is positively related to entrepreneurial intentions. The results of the research indicated that which perceived feasibility doesn't impact the perceived desirability, as most of the projects started with an idea and did not have any feasibility study. This proves that feasibility not have an effect on the desirability, but an interaction between desirability and feasibility may occur later when the project features and the risks surrounding and affecting it become clear. However, is indicated that there is an interaction among the factors of feasibility and desirability. MacIver et al. (1991) indicated that, in general, entrepreneurial intention aren 't just a task of the main impacts of feasibility and desirability, but also a task of the interaction among these factors, but that interaction may occur during, before or after the incubation period, and this is due to entrepreneurs and their level of perception of entrepreneurial action. Self-efficacy also has a positive statistical effect on feasibility. Self-efficacy is a strong indicator of entrepreneurial intentions as the likelihood of starting an activity can be explained by the individual's belief in his ability to implement a certain behavior. So, self-efficacy has a positive impact on entrepreneurial intentions. Thus, the objective of examining the factors affecting entrepreneurial intent has been achieved.

The fifth question is: "what is the level of entrepreneurial knowledge and skills for Yemeni businessmen?". The level of knowledge and entrepreneurial skills was measured by the educational level and source of information owned by the entrepreneurs. It was found that the majority of entrepreneurs have a university education, which means that their level of knowledge of business management is good. The sources of information that entrepreneurs possess about entrepreneurship were also measured. Most of the entrepreneurs have sources of information that came from academic courses, and others sources came from training courses, workshops, handbooks, and other sources such as reading, the Internet, or friends. The highest percentage of information sources is for academic courses, and this is due to the recent trend in universities to offer entrepreneurship courses in many disciplines. It is also due to the fact that some universities tend to open majors in entrepreneurship and encourage students to go into entrepreneurship. Therefore, nearly half of the entrepreneurs have the essential knowledge and skills to begin a business, to further refine skills, and to add other skills to ensure business success. They must join the incubator programs. Thus, the fifth goal, which aims at determining the level of knowledge and entrepreneurial skills of Yemeni businessmen, has been accomplished.

\section{Future Research}

This study suggests the necessity of conducting other studies on entrepreneurs for SMEs outside the incubation programs. Studies should include all incubators in the area covered by the study. Future researches are recommended to consider the following:

- Criteria for successful business incubators and incubated entrepreneurs.

- Challenges facing entrepreneurs and incubators in Yemen.

It is also suggested to conduct comparative research among the incubated and non-incubated entrepreneurs and to compare the extent of success and sustainability of each of them. A comparative research among the private and public business incubators is also recommended. The limitations of this research will be offer chances for future studies, as this research included a limited sample size. This may lead to doubts about the validity of the results for generalization in the future. Therefore, future researches may have a more representative sample for support or disprove the results of this research. Some incubator organizations were not willing to assist with this study, so the study was unable to determine whether the sample includes different forms of incubators and the kinds of services offered by the incubators. Further research can be conducted to cover these areas. Future studies can design programs for incubators that help the potential for more rapid growth and development of both incubators and entrepreneurs to make them more effective in contributing to the economic growth.

\section{Recommendations}

This study recommends the following:

Recommendations for the competent authorities:

- The competent authorities should conduct studies on determining the local industrial, service and production needs. Studies should be conducted to, determine the size of the market need in order to grant permission to open incubators according to their need and specialization. Incubators should not be opened without permission from the competent authorities and the process should be organized so that each incubator specializes in a specific activity or sector such as agricultural, technological, industrial, productivity. etc.

- There should be specific criteria and conditions for granting the permission so that the process is not random. 
- Competent authorities should provide a database for incubators and pioneers for reference when needed.

- Competent authorities should provide sufficient support for the operation of incubators from donors (international organizations, the private sector, the public sector)

Recommendations for the owners of the Yemeni business incubators:

- There should be an Organizing of entrepreneurial projects and nominating projects that deserve support and incubation and, those that actively contribute to the industrial and economic development.

- Owners of the Yemeni business incubator should provide more effective and specialized services for young entrepreneurs.

- Owners of the Yemeni business incubator should work to create an integrated entrepreneurial climate in terms of equipment, information, training, and relationships with prominent personalities in the field of business and major companies.

- It is recommended to deal with young entrepreneurs as future projects to supply the local market for companies of value.

- Preparing training and qualification programs for young entrepreneurs or at least six months and no more than a year is needed in order to prepare them for the labor market. Entrepreneurs should be provided with many training programs (administrative, leadership, marketing, finance, relationships, project management, etc.).

- Preparing a renewable database for the local market and emphasizing its need for the development of products and services.

- Owners of the Yemeni business incubator should provide valuable help and advice from experienced people in the local market in the form of workshops, lectures, or seminars.

- It is recommended to conduct a serious research for donors to support programs for young entrepreneurs at no cost in order to set conditions and standards for those wishing to enter the incubator and obtain services.

- It is recommended to focus on entrepreneurs and their success and support far from making the incubator a provider of place and services.

Recommendations for Yemeni entrepreneurs:

- Yemeni entrepreneurs should be serious in obtaining the most benefit from business incubators.

- Yemeni entrepreneurs should be obtaining the largest amount of training and qualification in the programs offered by the incubators.

- Yemeni entrepreneurs should be focus on a specific major they are good at.

- Yemeni entrepreneurs should be work on real feasibility studies for the project that they intend to work on.

- It is recommended to get benefit from the advice and directions that Yemeni entrepreneurs get from the incubator.

- Contracting with the incubator for the post-training phase as an approved consultant reference.

- Slow and focused steps are better than recklessness in establishing market projects that are saturated or new to the country's culture and unpalatable.

- It is recommended to carry out real market research for the needs of the local market in terms of products or services and has a market. Yemeni entrepreneurs' projects will gain market share even if they are traditional and appear in a modern form.

- It is recommended for Yemeni entrepreneurs to search for real donors to support their projects or microfinance agencies.

- It is recommended to search for opportunities to seize them during field visits, open meetings, and workshops, and to participate in economic forums.

\section{References}

Bandura, A. (1986). Social foundations of thought and action: A social cognitive theory. Englewood Cliffs, NJ: Prentice- Hall, Inc.

Bandura, A. (1991). Self-regulation of motivation through anticipatory and self-regulatory mechanisms. In R. A. Dienstbier (Ed.), Perspectives on motivation: Nebraska symposium on motivation (Vol. 38, pp. 69-164). Lincoln: University of Nebraska Press.

Bandura, A., \& Adams, N. E. (1977). Analysis of self-efficacy theory of behavioral change. Cognitive Therapy and Research, 1, 287-308. 
Barbosa, S. D., Gerhardt, M.W. \& Kickul, J. R. (2007). The role of cognitive style and risk preference on entrepreneurial self-efficacy and entrepreneurial intentions. Journal of Leadership and Organizational Studies. 13 (4), 86-104.

Barton, M., Schaefer, R., Canavati, S. (2018). To be or not to be a social entrepreneur: Motivational drivers amongst American business students. Entrep. Bus. Econ. Rev, 6, 9-35.

Boukamcha, F. (2015). Impact of training on entrepreneurial intention: An interactive cognitive perspective. Eur. Bus. Rev .27, 593-616.

Brockner, J., Higgins, E.T., \& Low, M.B. (2004). Regulatory focus theory and the entrepreneurial process. J. Bus. Ventur. 19(2), 203-20.

Buys, A. J., \& Mbewana, P. N. (2007). Key success factors for business incubation in South Africa: The Godisa case study. South African Journal of Science, (103), 357-358.

Chen, C. C., Greene, P. G., \& Crick, A. (1998). Does entrepreneurial self-efficacy distinguish entrepreneurs from managers? Journal of Busi-ness Venturing, 13, 295-316

De Noble, A., Jung, D., \& Ehrlich, S., (1999). Entrepreneurial self-efficacy: The development of a measure and its relationship to entrepreneurial action. In R. D. Reynolds et al. (eds.), Frontiers of entrepreneurship research, (pp. 73-78). Waltham, MA: P y R Publication Inc.

Dickson, P. R., \& Giglierano, J. J. (1986). Missing the boat and sinking the boat: A conceptual model of entrepreneurial risk. Journal of Marketing, 50 (3), 58-70.

Ebben, J. \& Johnson, A., (2005). Efficiency, flexibility, or both? A link between strategy and performance in small firms. Strategic Management Journal, 26, 1249-1259.

Echetama, F. C., Obi, C., \& Joel, A. D., (2016). Effect of feasibility study on the growth of SMEs in Imo-State: A study of selected SMEs in Owerri Zone. International Journal for Research in Business, Management and Accounting, 2 (2), 10.

Edelman, L., \& Yli-Renko, H. (2010). The impact of environment and entrepreneurial perceptions on venturecreation efforts: Bridging the discovery and creation views of entrepreneurship. Entrepreneurship: Theory \& Practice 34 (5), 833-856.

Fedáková, D., Studená, I., \& Kožárová, Z. (2018). Entrepreneurial risk perception and entrepreneurial intention of employed and unemployed in the context of entrepreneurial individual resources. Individual and Society, 21(2), 31-46.

Fellnhofer, K. (2017). A framework for a teaching toolkit in entrepreneurship education. Int J Contin Eng Educ Life Long Learn, 27(3), 246-261.

Finisterra Do Paço, A. M., Matos, J., Raposo, M., Gouveia, R., \& Dinis, A., (2011). Behaviours and entrepreneurial intention: empirical findings about secondary students. Journal International Entrepreneurship, 9, 20-38.

Freeman, J. H., Carroll, G. R., \& Hannan, M. T. (1983). The liability of newness: Age dependence in organizational death rates. American Sociological Review, 48, 692.

Gifford, S. (2010). Risk and uncertainty. In Z. Acs, \& D. Audretsch (eds.), Handbook of entrepreneurship research (pp. 303-318). New York: Springer.

Gordon Institute of Business and Science. (2009). The entrepreneurial dialogues. State of Entrepreneurship in South Africa. The FNB Conference Centre. Retrieved from http://www.gibs.co.za/SiteResources/documents/The\%20Entrepreneurial\%20Dialogues\%20$\% 20$ State\%20of\%20Entrepreneurship\%20in\%20South\%20Africa.pdf [6 June 2014]

Hackett, S. M. \& Dilts, D. M. (2004). A Systematic review of business incubation research,' Journal of Technology Transfer 29 (1), 55-82

Janney, J., \& Dess, G. (2006). The risk concept for entrepreneurs reconsidered: New challenges to the conventional wisdom. Journal of Business Venturing, 21, 385-400.

Keh, H.T., Foo, M. D. \& Lim B. C. (2002). Opportunity evaluation under risky conditions: The cognitive processes of entrepreneurs. Entrepreneurship: Theory \& Practice 27 (2), 125-148.

Kickul, J. (2006). Pathways to new business opportunities: Innovations and strategies for the entrepreneurial classroom. In A. Fayolle, \& H. Klandt (eds.), international entrepreneurship education: Issues and Newness (pp. ,168-182) UK: Edward Elgar.

Krafft, C. and Rizk, R. (2021), The promise and peril of youth entrepreneurship in the Middle East and North Africa, International Journal of Manpower, Vol. ahead-of-print No. ahead-ofprint. https://doi.org/10.1108/IJM-05-2020-0200

Krueger, N. F. (2009). Entrepreneurial intentions are dead: Long live entrepreneurial intentions. In A. Carsrud, \& M. Brännback (eds.), Understanding the entrepreneurial mind: Opening the black box (pp. 51-72). Nueva York: Springer.

Krueger, N. F. \& Brazeal, D. V. (1994). Entrepreneurial potential and potential entrepreneurs. Entrepreneurship: Theory and Practice, 18, 91-104. 
Krueger, N.F., Reilly, M.D. \& Carsrud, A. L. (2000). Competing models of entrepreneurial intentions. Journal of Business Venturing, 15(5-6), 411-432.

Kuehn, K. (2008). Entrepreneurial intentions research: Implications for entrepreneurship education. Journal of Entrepreneurship Education 11, 87-98.

Lalkaka, R., \& Shaffer, D. (1999). Nurturing entrepreneurs, creating enterprises: Technology business incubation in Brazil. In Proceedings of the International Conference on Effective Business Development Services, Rio de Janeiro, Brazil. 3, 2-3.

Leitch, C. M., Hill, F. M., \& Harrison, R. T. (2010). The philosophy and practice of interpretivist research in entrepreneurship. Quality, validation, and trust. Organizational Research Methods, 13, 67-84.

Liñán, F., \& Y. Chen, Y. (2009). Development and cross-cultural application of a specific instrument to measure entrepreneurial intentions. Entrepreneurship: Theory \& Practice 33 (3), 593-617.

MacIver, D., J., Stipek, D. J., \& Daniels, D. H. (1991). Explaining within-semester changes in student effort in junior high school and senior high school courses. Journal of Educational Psychology, 83, 201-211.

Martínez, K. R. G., Herrero-Crespo, Á., \& Fernandez-Laviada, A. (2015). Influence of perceived risk on entrepreneurial desirability and feasibility: Multidimensional approach for nascent entrepreneurs. Journal of Risk Research. DOI: 10.1080/13669877.2015.1042506.

McGee, J. E., Peterson, M., Mueller, S. L., \& Sequeira, J., (2009). Entrepreneurial self-efficacy: Refining the measure. Entrepreneurship: Theory and Practice, 33(4).

Meru, A., \& Struwig, M. (2011). An evaluation of the entrepreneurs' perception of Business-incubation services in Kenya. International Journal of Business Administration. 2 (4), 112-121.

Ndedi, A. A. (2009). Entrepreneurship training and job creation in South Africa: Are tertiary institutions filling the gap? Journal of Contemporary Management. 6, $463-470$.

Nesta (2011). Vital growth, London : NESTA https://media.nesta.org.uk/documents/incubation_for_growth_CqYbxVG.pdf

Obschonka, M., Silbereisen, R. K. \& Schmitt - Rodermund, E. (2010). Entrepreneurial intention as developmental outcome. Journal of Vocational Behavior ,77,63-72.

Peterman, N. E., and Kennedy, J. (2003). Enterprise education: Inflluencing students' perceptions of entrepreneurship. Entrepreneurship theory and Practice, 28 (2), 129-144.

Pomba, C. (2013). Literature review on the impact of business incubation, mentoring, investment and training on start-up companies. $\quad$ EPS-PEAKS. Retrieved from http://r4d.dfid.gov.uk/pdf/outputs/EPS/Literature_Review_on_the_Impact_of_Incubation_Investment_Trai ning20.pdf

Ratten, V. (2020), Entrepreneurship as Empowerment: Knowledge Spillovers and Entrepreneurial Ecosystems, Ratten, V. (Ed.) Entrepreneurship as Empowerment: Knowledge Spillovers and Entrepreneurial Ecosystems, Emerald Publishing Limited, Bingley, pp. 1-10.

Ratten, V. and Dana, L.-P. (2019), Societal Entrepreneurship and Competitiveness, Dana, L.-P. and Ratten, V. (Ed.) Societal Entrepreneurship and Competitiveness, Emerald Publishing Limited, Bingley, pp. 1-4.

Roscoe, J. T. (1975). Fundamental research statistics for the behavioral sciences. New York:

Holt, Rinehart and Winston.

Schwartz, M. (2011). Incubating an illusion? Long-term incubator firm performance after graduation. Growth and Change, 42, 491-516.

Segal, G., Borgia, D., Schoenfeld, J. (2005). The motivation to become an entrepreneur. Int. J. Entrep. Behav. Res. 11, 42-57.

Shapero, A., \& Sokol, L., (1982). The social dimension of entrepreneurship. In: C.A. Kent, D. L. Sexton, \& K. H. Vesper (eds.), The encyclopedia of entrepreneurship. Englewood Cliffs, NJ.: Prentice- Hall.

Singh, I., Prasad, T. \& Raut, R. (2012). Entrepreneurial intent-A Review of Literature. Ninth AIMS International Conference on Management, January 1-4.

Steel, P., \& Konig, C. J. (2006). Integrating theories of motivation. Academy of Management Review, 31, 889913.

Stephens, S., \& Onofrei, G. (2012). Measuring business incubation outcomes: An Irish case study. The International Journal of Entrepreneurship and Innovation 13 (4), 277-285.

Thompson, E. R. (2009). Individual entrepreneurial intent: Construct clarification and development of an internationally reliable metric. Entrepreneurship: Theory \& Practice, 33 (3), 669-694.

Wiggins, J., \& Gibson, D. V. (2003). Overview of US incubators and the case of the austin technology incubator. International Journal of Entrepreneurship and Innovation Management, 3 (1-2), 56-66. Retrieved from: http://inderscience.metapress.com/content/165pypyf3qfxhfm2/

Wirsing, B., Traude, A., Steffens, J., Sheen, M., Löffler, B., de Lapparent, D., Broadfoot, C., \& Alonso-Gonzalez, J. (2002). Becoming an entrepreneur for a trial period: The pre-incubation experience. The International Journal of Entrepreneurship and Innovation 3 (4), 265-277. 


\section{Copyrights}

Copyright for this article is retained by the author(s), with first publication rights granted to the journal. This is an open-access article distributed under the terms and conditions of the Creative Commons Attribution license (https://creativecommons.org/licenses/by-sa/4.0/). 